\title{
C.M. NAIM
}

\section{The Situation of the Urdu Writer: A Letter from Bara Banki, December 1993 / February 1994}

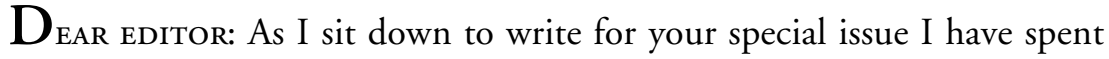
almost three months in Bara Banki, a small town in northern India, thousands of miles away from the seminars on literature at Chicago. On the other hand, Bara Banki is only seventeen miles from Lucknow, the fast-decaying capital of the state of Uttar Pradesh, which was once famous for its elegant, Urdu-dominated culture; it is also only seventy miles away from Ayodhya, where exactly one year ago a frenzied mob, led by some very deliberate people, tore down a sixteenth-century mosque. A few weeks ago, at a mushäira or poetry reading attended by several hundred people, I heard a young Urdu/Muslim poet recite a banal verse which nevertheless drew loud applause: "They all love me, but none is 'mine' / I exist in this country like Urdu." Given these circumstances, I feel little inclined to discuss "magic realism" in Urdu fiction or the decline of the "abstract" story in this "postmodernist" period. I can only talk about Urdu and what it is like to be an Urdu writer in India today, in this fortysixth "postcolonial" year. So bear with me.

Urdu is one of the sixteen or eighteen constitutionally recognized major languages in India, and I am told that the 198I census showed it to have some 35 million speakers. There is, however, no region specific to it. Years ago, for some obscure political reason, it was declared to be a state language in Kashmir, but the mother tongues of the people of that beleaguered state are Kashmiri, Dogri, and Ladakhi, not Urdu. On the

(C) WLT [World Literature Today, 68:2 (Spring 1994): 245-46], with permission of the Editor. 
other hand, in the states where millions of Urdu speakers have lived and died for centuries, Urdu has no status, not even that of a full-fledged second language. (My mother recently wrote her will in Urdu but, in order to get it legally registered, had to have it translated into Hindi.) Urdu-speaking children in Lucknow and Bara Banki do not receive primary or secondary education in Urdu. (I write to my sister in Urdu; she must correspond with her sons in Hindi.)

Perhaps I should say that the Urdu-speaking children in northern India cannot receive primary or secondary education in their mother tongue-guaranteed to them in the Indian Constitution-because the state refuses to provide it. In fact, the state has put an end to what was available even during the colonial period. When this happened, soon after India became independent, many Muslim parents started sending their children to what were then and still primarily are religious schools: the madrasas. Previously there, children learned to vocalize/memorize the Qur'ān-without understanding a word of it—and the basics of the Islamic faith. Now, in that same context, they are taught to read and write Urdu, but little else. Eventually they return to the regular schools and find themselves trailing behind their peers in almost every subject. Better Muslims, perhaps, but handicapped for the mundane competitions of life, and not really true heirs to all that was always claimed for Urdu.

One invariable claim made about Urdu was that it stood for synthesis and harmony, that it represented the commingling of Iran and India, of Muslims and Hindus. Now such a claim would make little sense. Today, in India, Urdu is almost exclusively a language of the Muslims. But not of all Muslims. Not, for example, of the Muslim peasants or fishermen in Bengal and Kerala, nor of the illiterate, lower-class Muslim women in northern Indian towns and villages. At best, it is the language of high culture for the vast majority of urban Muslims, particularly men, more particularly in northern India. It is they who feel culturally most threatened by the state antagonism to Urdu. They may be the people most of whose elders not too long ago raised the cry of Muslim nationalism and created Pakistan, but must the "sins" of the fathers be visited upon the children?

"Urdu is such a sweet language." I dare not count the times I have heard this from speakers of other Indian languages when they discover that I speak and teach Urdu. But does their own language not sound sweet to their ears? How do they measure this "source" in Urdu? Unfortunately, all that is meant is that they enjoy a certain kind of singing and take delight in going to movies with such titles as Mére 
Mahbūb (My Beloved), Pākiza (The Pure One), and Čaudhvīn kā Čānd (The Full Moon). Urdu, for them is ghazal poetry and the culture of the courtesan and her patron. It would appear that the sweetness of Urdu lies in what in other contexts is called decadent and "feudalistic."

Then there are those Urdu speakers who proudly assert, "Urdu is the sweetest language of all." They too have something similar in mind, except that they view it as cultural sophistication. Curiously, I have never heard an Urdu speaker call Marathi or Tamil sweet. I have, however, heard them use that term concerning such northern Indian "dialects" as the Braj or the Avadhi-in this case, invoking the image of village belles, love songs, and rustic ways. In other words, to be called "sweet," a language must be perceived as something remote, a part of the nostalgia, even carrying a whiff of decay. To see Urdu's future in India in the increasing number and popularity of ghazal singers is macabre-as macabre as the "muslim" set designs for the ghazal shows on Indian television, the same television that has only five minutes of daily news in Urdu in Lucknow and just one more Urdu program of thirty minutes each week. And yet, the Ministry of Information and Broadcasting of the government of India spends a great deal of effort and money on several hours of a daily program on short wave called "Urdu Majlis," beamed at Pakistan!

No wonder serious Urdu writers in India form a curious breed: they have to keep surfacing despite the challenges that surround them. Suppose you are a bright young person growing up in a caring, not exactly indigent Urdu-speaking family in northern India. By huge odds, you must be a Muslim too. You would be taught to vocalize the Qur'ān at home by a maulvi, who might also teach you to read and write Urdu. But your parents would not find any Urdu-medium primary or secondary school in the city, not to mention the neighborhood, and even if they did, it would be so bad they would not send you to it. So you would go to some private school (English-medium) or some state school (Hindimedium). By the time you reach high school, where Urdu might be available as an optional subject, very little Urdu would be left in you. Anyway, that is the time for extra course work in science and math and English, to prepare yourself for the university.

But perhaps you are the persistent kind; you find the time to read in Urdu on your own. How do you get the books? Urdu collections in public libraries have not been maintained; in some instances, in northern India, they were even disposed of in various ways. In bookstores only a tiny fraction of the literature is available, for most of it has not been 
republished or gone beyond one printing since 1947. Shipments of books and magazines from Pakistan are rarer still; it is easier to order a book from Brooklyn than from Karachi. What this means is that most Urdu writers in India have little or no knowledge of several generations of poets and novelists of the erstwhile united India, and only a rare few of them have any access to the wealth of Urdu publications in Pakistan.

But let's return to your desire to write in Urdu. You have managed to obtain the linguistic tools, read enough in your tradition, and found your inspiration. You start writing, say, short stories. There are a dozen or so literary magazines to send them to; but fewer than half of these come out regularly, and none has a circulation of more than a thousand copies, except the one published by the Information Ministry. It is also the only one that pays its contributors even a nominal amount. Of course, it only publishes what it considers "safe."

So you persist, and in a couple of years you have a dozen stories to make up a book. Now you look for a publisher. Easy, if you don't ask for money and, on the contrary, are able to bring a subsidy from one of the state-sponsored Urdu academies. If, however, you are not in with the ignorant bureaucrats or their imbecilic advisors from academia, you have no choice but to publish the book yourself. Average first edition: 400 to I, Ooo copies.

Congratulations! You now have a book out, but will it sell? A lucky first edition sells out in two to four years. That is the end of your book, unless someone brings out a pirated edition in Pakistan. In fact, you secretly long that someone will. How else will you reach that other audience of yours?

Of course, while all this was going on, you were also trying to find and hold a job, to raise a family. Then one day your daughter comes home from school and tearfully shows you her Hindi or history textbook. It says that the Muslims were aliens in India, that they only destroyed temples and persecuted the Hindus and made no positive contribution, that they must be "brought back into the mainstream of Indian life." Or your son tells you how he was taunted by some boys who called him a "Babur's son." (Babur was the Central Asian prince who conquered parts of northern India in 1526 and laid the foundation for what later came to be known as the Mughal dynasty.) What do you say to them? Or perhaps you have the experience yourself when you go to the corner store and find written on its wall in crude letters: "Babur's children, / Go to your graves or to Pakistan!" Should you then not find it amusing that even the ugly slogan aimed at you was written in Hindi while, conversely, it used a 


\section{i24 - The Annual of Urdu Studies}

jingle form that imitated Urdu? Perhaps not. Hashimpura, Maliana, Bhagalpur, Meerut, Bhiwandi, Baroda, Ahmedabad, Hyderabad, Bombay, Surat, Bhopal-what happened in these and many other places was far from amusing.

So, you return home and write a story, in Urdu. For writing in Urdu in India is now definitely a political act. It may not empower you much, but it still lets you assert the fact of your existence. You authorize yourself. In a time of plagues, that is enough. 